\title{
Development of optimum substrate compositions in the methane fermentation process
}

\author{
Justyna Lalak*, Agnieszka Kasprzycka, Ewelina M. Paprota, Jerzy Tys, and Aleksandra Murat \\ Institute of Agrophysics, Polish Academy of Sciences, Doświadczalna 4, 20-290 Lublin, Poland
}

Received February 24, 2014; accepted March 22, 2015

\begin{abstract}
A b s t r a c t. The aim of the study was to assess the potential of organic wastes from the agriculture and food industry as co-substrate for biogas production, on the basis of physical and chemical parameters analysis and biogas yield in the process of methane fermentation. The experimental material consisted of carrot pomace, kale by-products and maize silage. Methane fermentation was conducted in bioreactors equipped with an automatic control and measurement system. The study indicated correct physicochemical properties in terms of high content of dry organic matter and also correct $\mathrm{C} / \mathrm{N}$ ratio. That was reflected in high biogas yields which amounted to, respectively, $558 \mathrm{~N} \mathrm{dm}^{3} \mathrm{~kg}^{-1}$ $\mathrm{VS}^{-1}$ for carrot pomace and kale by-products, and $526 \mathrm{~N} \mathrm{dm}^{3}$ $\mathrm{kg}^{-1} \mathrm{VS}^{-1}$ for maize silage. The study showed that the intensity of biogas production was varied and depended on the composition of fermented mixtures. Methane fermentation of organic waste mixtures significantly increased the amount of biogas efficiency compared to the fermentation of individual substrates. The successful run of the experiment indicates that a mixture composed of carrot pomace and kale by-products is a good substrate for the production of biogas.
\end{abstract}

$\mathrm{K}$ e y w o r d s: methane fermentation, methane, biogas, biodegradable wastes

\section{INTRODUCTION}

In recent years one of the main problems faced by industrialized countries is environmental pollution. This is related primarily with intensification of agricultural and livestock production and with increased degree of processing of agricultural food products. For some time now one can observe a significant increase in the amount of organic wastes and contaminants produced in agriculture and related branches. Those wastes are rich in components necessary for the growth and development of microorganisms, such as carbohydrates, lipids, proteins, microelements, biogenic elements and vitamins (Esposito et al., 2012). They may appear in solid, semi-liquid and liquid forms. Leaving such wastes in their raw state may cause

\footnotetext{
*Corresponding author e-mail: j.lalak@ipan.lublin.pl
}

specific environmental problems and sanitary threats. The biodegradation of wastes results in the emission of gases (ammonia, methane, hydrogen sulphide, carbon dioxide and nitrous oxides) to the atmosphere, and in the 'seepage' of biogenic compounds (of nitrogen, phosphorus, potassium) to surface and ground waters. Uncontrolled seepage of biogenic compounds leads to disturbances in the balance of the ecosystem and to increased eutrophication of waters. Taking into account the necessity of neutralization of agricultural wastes and those from the food industry, the most suitable and economical methods of degradation of wastes are the biotechnological methods which permit the transformation of organic wastes into energy and valuable products such as fodder and fertilizers (Börjesson and Berglund, 2006; Kotner, 2011).

Lately great hopes are placed on the utilization of biogas formed through methane fermentation of agricultural and food industry biomass. Methane fermentation is a several-stage biochemical process taking place under controlled anaerobic conditions as a result of specific bacterial environment operation. That process proceeds in four stages. The first stage takes place with participation of hydrolytic bacteria which degrade insoluble polymeric organic compounds to simpler forms. The simple compounds formed in the first stage are processed by acidic bacteria, and then by acetate bacteria which, in the third stage, produce acetate. Finally, methanogens convert these products to biogas. The fermentation gas is a mixture of gases whose relative proportions are subject to notable variation. Under optimum process conditions, the fermentation gas is composed of methane (52-85\%), carbon dioxide (14-48\%), hydrogen sulphide (0.08-5.5\%), hydrogen $(0-5.5 \%)$, carbon monoxide $(0-2.1 \%)$, nitrogen $(0.6$ $7.5 \%)$ and oxygen (0-1\%) (Oleszek et al., 2013).

(C) 2015 Institute of Agrophysics, Polish Academy of Sciences 
The use of methane fermentation process for organic waste degradation is attractive for several reasons (Barton et al., 2008; Esposito et al., 2012; Lettinga, 2001), this technology not only reduces the volume of organic waste to be disposed and avoids soil and groundwater pollution, but also makes available renewable and low-cost energy, for example biogas, that, unlike the fossil fuels, keeps stable the balance of greenhouse gases, such as $\mathrm{CO}_{2}$, in the atmosphere. Moreover, methane fermentation process of organic waste represents a reasonably low-cost and lowtechnology system to supply energy for rural areas in developing as well as underdeveloped countries where the main cause of their economic and social backwardness can be reasonably attributed to the lack of suitable energy. Biogas is already effectively used to produce electricity and heat, and to feed gas networks (Bekkering et al., 2010; Esposito et al., 2012). A further source of income produced by the process of methane fermentation of organic solids is represented by the semi-solid by-product of this process - post-fermentation sludge - that thanks to its high content of nutrients can be used in agriculture directly as a fertilizer or processed into compost to increase its quality (Esposito et al., 2012; Rehl and Müller, 2011; Tambone et al., 2009). Unfortunately, methane fermentation process has substantial drawbacks. Those include difficulties related with maintaining an appropriate concentration of microorganisms in reactor, higher sensitivity to changes in reaction and temperature. Furthermore, methane fermentation process does not always cause complete degradation of organic materials. Besides, it requires heating of wastes to carry out the fermentation under mesophilic or thermophilic conditions. Additionally, odour nuisance is observed in the case of unsuccessful hermetization of bioreactors and containers designed for the storage of biomass (Ziemiński and Frąc, 2012).

Many different kinds of biomass containing proteins, lipids, carbohydrates and lignocellulose, as the main components, are suitable to be used as feedstock for biogas production. Energy crops (eg Miscanthus, Sudan grass), organic wastes from agriculture-related factories, food waste, meat and fish industrial wastes, dairy wastes, collected municipal organic solid waste from markets, sewage sludge from aerobic wastewater treatment and animal manure, are the substrates commonly used for feeding bioreactors (Esposito et al., 2012).

The composition of fermentation gas depends mainly on the kind of substances that undergo degradation in the digester chamber. Carbohydrates and proteins show faster conversion rates but lower gas yields, whereas lipids provide the highest biogas yield but require a long time due to their slow biodegradability. Gas with the highest content of methane (best in terms of quality) is obtained as a result of degradation of protein (Esposito et al., 2012; Frąc and Ziemiński, 2012; Momoh and Nwaogazie, 2011).
Carbohydrates are commonly present in food waste, organic wastes from agriculture-related factories. Methane fermentation process of carbohydrates is strongly dependent on the ratio between the methanogenic process rate and the acidification process rate. For example, if the acidification process is faster than the methanogenic process, volatile fatty acids (VFAs) tend to accumulate in the bioreactor, causing progressive drops in $\mathrm{pH}$ that stress and inhibit the activity of anaerobic bacteria (Siegert and Banks, 2005).

Lipids are the main components of food wastes and industrial wastewaters, such as those produced by dairies, slaughterhouses or fat refineries. Lipids are attractive for biogas production because of the high content of carbon and hydrogen atoms in their molecule, which implies a high theoretical methane potential. On the other hand, they can also present problems such as inhibition of methanogenic archaea and adsorption onto biomass that can cause sludge flotation. The rate of degradation depends primarily on the characteristics and mass of the raw material, on the temperature, and on optimum choice of process duration (Esposito et al., 2012; Neves et al., 2009).

Biomass with a high content of proteins - nitrogen is mainly produced by livestock husbandry (animal slurry, manure) and also by meat processing factories. These wastes are rich in nitrogen and present high biological oxygen demand (BOD) and high organic matter content, but low $\mathrm{C} / \mathrm{N}$ ratio (Cuetos et al., 2010). During methane fermentation process of this waste, an increase of ammonia concentration occurs (Chen et al., 2008). The problem can be that ammonia can cause inhibition of anaerobic digestion (Nielsen and Angelidaki, 2008).

Carrot pomace and kale by-products are lignocellulosic materials produced in large quantities during the process of juice extraction in the industry. Although these agricultural residues may be used as an animal feed, they are usually discarded as waste (Yoon et al., 2005). For example, in Taiwan juice processing companies produce about six thousand tons of carrot pomace annually (Chi-Yang et al., 2013), and about $100 \mathrm{t}$ of kale pomace is produced in Poland (Cybulska et al., 2013).

The objective of the study presented here was to determine the potential of organic wastes from the agriculture and food industry as a co-substrate for the production of biogas, on the basis of analysis of physical and chemical properties and of biogas yield in the process of methane fermentation.

\section{MATERIALS AND METHODS}

The experiment was divided into five experimental series (Table 1). The criterion for the division was the composition of the substrate mix in the process of methane fermentation. 
T a b l e 1. Characteristics of components for the digesters

\begin{tabular}{cccc}
\hline \multirow{2}{*}{$\begin{array}{c}\text { Feedstock } \\
\text { No. }\end{array}$} & $\begin{array}{c}\text { Kale } \\
\text { by-products }\end{array}$ & $\begin{array}{c}\text { Carrot } \\
\text { pomace }\end{array}$ & Maize silage \\
\cline { 2 - 4 } 1 & 100 & 0 & 0 \\
2 & 0 & 100 & 0 \\
3 & 50 & 50 & 0 \\
4 & 0 & 50 & 50 \\
5 & 0 & 0 & 100 \\
\hline
\end{tabular}

1 -kale by-products; 2 - carrot pomace, 3 -kale by-products:carrot pomace $1: 1 ; 4$ - carrot pomace:maize silage $1: 1 ; 5$ - maize silage.

T a b l e 2. Instrumental parameters of ICP-OES

\begin{tabular}{lc}
\hline Parameter & Value \\
\hline RF power & $1150 \mathrm{~W}$ \\
Frequency of RF generator & $27.12 \mathrm{MHz}$ \\
Auxiliary flow & $0.41 \mathrm{~min}^{-1}$ \\
Coolant gas flow rate & $161 \mathrm{~min}^{-1}$ \\
Carrier gas flow rate & $0.651 \mathrm{~min}^{-1}$ \\
Pump rate & $50 \mathrm{r.p.m}$. \\
Viewing configuration & Axial \\
\hline
\end{tabular}

Anaerobic digester sludge was obtained from a biogas plant in Siedliszczki, Poland. The sludge had pH of 7.207.28 and contained on average $4.47 \%$ total solids and $31.57 \%$ total volatile solids.

Before starting the process of methane fermentation, the substrates were subjected to chemical analyses. Total solids (TS), volatile solids (VS) and ash were determined using the gravimetric method after drying at 105 and $550^{\circ} \mathrm{C}$, according to PN-EN 12880:2004 and PN-EN 12779:2004. The analysis of total organic carbon (TOC) was performed on the TOC-V CPN analyzer with solid sample combustion unit SSM-5000A, according to the manufacturer protocol. Total nitrogen was estimated by the Kjeldahl method. Ammonium nitrogen was measured by spectrophotometry. Macro- and microelements were tested by the Inductive Coupled Plasma-Optical Emission Spectrometer (ICP OES, Thermo Scientific iCAP Series 6500). The samples of materials were subjected to digestion using a microwave mineralizer Berghoff Speedwave Four in Teflon vessels DAP 100 , in order to determine the content of individual elements. The mineralization was conducted with the use ofa

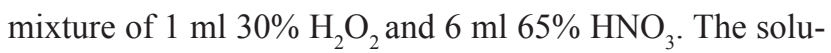
tions were analyzed by ICP-OES, equipped with a charge injection device (CID) detector and TEVA software. A multi- element standard solution for ICP-OES containing 6 elements: $\mathrm{Cu}, \mathrm{Fe}, \mathrm{Mg}, \mathrm{P}, \mathrm{K}$, and $\mathrm{Na}$ (Analityk-46, 1000 ppm) and a multi-element standard solution containing 5 elements: B, Ba, Li, S, and Si (Analityk-47, 40 ppm) obtained from Inorganic Ventures (US, Virginia) were used for standardization. The wavelengths of $181 \mathrm{~nm}$ for S, $186 \mathrm{~nm}$ for P, $285 \mathrm{~nm}$ for $\mathrm{Mg}, 589 \mathrm{~nm}$ for $\mathrm{Na}$, and $766 \mathrm{~nm}$ for K were used. ICP-OES operational parameters are given in Table 2.

In the course of the study analyses were made of the parameters of importance from the viewpoint of the process of methane fermentation ie total solids and volatile solids.

Mesophilic methane fermentation was performed according to the VDI 4630 protocol (2006). Fermentations were carried out in a 21 Biostat $^{\circledR}$ B-plus stirred tank reactor (Sartorius Stedim Biotech, Gottingen, Germany). The temperature of the process was $37^{\circ} \mathrm{C}$. The initial loading of $60 \mathrm{~g} \mathrm{VS} \mathrm{l}^{-1}$ and substrate to inoculum ratio (S/I) of 1:1 (based on the VS) were established. The $\mathrm{pH}$ of the fermentation mass was adjusted to 7.0 with sodium bicarbonate. Anaerobic conditions were created by blowing the whole volume of the reactor with nitrogen. Once a day, the composition of biogas was determined by means of multigas monitor (GFM436, Gas Data, UK). The volume of biogas was determined by the method of liquid displacement (Oleszek and Tys, 2013). The process was conducted in three independent replications until the moment when the daily yield was less than $1 \%$ of the total biogas yield obtained till then. The biogas and methane yield were calculated as follows (Yuan et al., 2014):

$$
\text { Biogas yield }=\frac{\text { biogas volume }_{\text {total }}-\text { biogas volume }}{\text { control }} \text {, }
$$

Methane yield $=\frac{\text { methane volume }_{\text {total }}-\text { methane volume }}{\text { control }}$,

where: biogas yield and methane yield $\left(\mathrm{dm}^{3} \mathrm{~kg}^{-1} \mathrm{VS}^{-1}\right)$.

The obtained values of biogas volume were converted to the normal conditions $(1013 \mathrm{hPa}, 273 \mathrm{~K})(38414-8$, 1985; Oslaj et al., 2010) as indicated by the Eq. (3):

$$
V=\left(\frac{273}{T}\right)\left(\frac{P}{1013}\right) V\left(\mathrm{CO}_{2}+\mathrm{CH}_{4}\right)
$$

where: $T$ is room temperature (Kelvin), $P$ is the atmospheric pressure in the laboratory at room temperature (hPa), $V$ is the $\mathrm{CO}_{2}$ and $\mathrm{CH}_{4}$ volume from the sample vessel under standard conditions in litres.

Data obtained from the analysis of chemical and elemental composition of organic waste (Tables 3 and 4) and physicochemical properties of the methane fermentation process (Table 5) were presented as the mean \pm standard deviation (SD). Statistical significance of differences in parameters between particular feedstock substrates was 
T a b l e 3. Physicochemical characteristics of organic waste

\begin{tabular}{|c|c|c|c|c|}
\hline \multirow{2}{*}{ Parameter } & \multirow{2}{*}{ Unit } & \multicolumn{3}{|c|}{ Bio-waste (Mean \pm S.D.) } \\
\hline & & Kale by-products & Carrot pomace & Maize silage \\
\hline TS & wet weight $\%$ & $22.29 \pm 0.32 \mathrm{a}$ & $11.27 \pm 0.27 \mathrm{~b}$ & $38.2 \pm 0.16 \mathrm{c}$ \\
\hline VS & $\mathrm{TS} \%$ & $91.27 \pm 0.21 \mathrm{a}$ & $92.10 \pm 0.18 b$ & $95.6 \pm 0.09 c$ \\
\hline $\mathrm{ASH}$ & $\mathrm{TS} \%$ & $8.73 \pm 0.21 \mathrm{a}$ & $7.9 \pm 0.18 b$ & $4.4 \pm 0.09 \mathrm{c}$ \\
\hline TOC & $\mathrm{TS} \%$ & $36.3 \pm 0.41 \mathrm{a}$ & $43.21 \pm 0.20 \mathrm{~b}$ & $55.7 \pm 0.35 \mathrm{c}$ \\
\hline $\mathrm{C} / \mathrm{N}$ & - & $25.03 \pm 0.32 \mathrm{a}$ & $28.42 \pm 0.52 b$ & $29.7 \pm 0.45 \mathrm{c}$ \\
\hline COD & $\mathrm{mg} \mathrm{O}_{2} \mathrm{dm}^{-3}$ & $1450 \pm 13.2 \mathrm{a}$ & $870 \pm 11.4 b$ & $1100 \pm 23.1 \mathrm{c}$ \\
\hline $\mathrm{N}_{\mathrm{am}}$ & $\mathrm{TS} \%$ & $0.11 \pm 0.02 \mathrm{a}$ & $0.41 \pm 0.11 b$ & $0.16 \pm 0.06 \mathrm{c}$ \\
\hline $\mathrm{N}_{\text {org. }}$ & $\mathrm{TS} \%$ & $1.45 \pm 0.11 \mathrm{a}$ & $1.52 \pm 0.06 \mathrm{~b}$ & $1.87 \pm 0.09 \mathrm{c}$ \\
\hline $\mathrm{pH}$ & $\mathrm{pH}$ & $4.58 \pm 0.01 \mathrm{a}$ & $3.93 \pm 0.02 b$ & $3.75 \pm 0.01 \mathrm{c}$ \\
\hline
\end{tabular}

TS - total solids, VS - volatile solids, TOC - total organic carbon, $\mathrm{N}_{\text {org. }}$ - organic nitrogen, $\mathrm{N}_{\mathrm{am}}-$ ammonium nitrogen, COD - chemical oxygen demand. Values with different superscript letter in the same column differ significantly at $\mathrm{p}<0.05$.

T a b l e 4. Elemental composition of organic waste

\begin{tabular}{cccc}
\hline & \multicolumn{3}{c}{ Bio-waste (Mean \pm S.D. $)$} \\
\cline { 2 - 4 } $\begin{array}{c}\text { Parameter } \\
\left(\mathrm{mg} \mathrm{kg}^{-1}\right)\end{array}$ & $\begin{array}{c}\text { Kale } \\
\text { by-products }\end{array}$ & $\begin{array}{c}\text { Carrot } \\
\text { pomace }\end{array}$ & Maize silage \\
\hline $\mathrm{K}$ & 13503.32 & 8645.33 & 5423.02 \\
& $\pm 145.02 \mathrm{a}$ & $\pm 170.22 \mathrm{~b}$ & $\pm 145.25 \mathrm{c}$ \\
$\mathrm{P}$ & 3862.33 & 2571.67 & 3722.33 \\
& $\pm 55.03 \mathrm{a}$ & $\pm 70.07 \mathrm{~b}$ & $\pm 25.13 \mathrm{c}$ \\
$\mathrm{S}$ & 1153.00 & 896.95 & 599.00 \\
& $\pm 56.32 \mathrm{a}$ & $\pm 12.36 \mathrm{~b}$ & $\pm 45.36 \mathrm{c}$ \\
$\mathrm{Mg}$ & 1642.00 & 1270.00 & 1791.00 \\
& $\pm 63.78 \mathrm{a}$ & $\pm 43.12 \mathrm{~b}$ & $\pm 33.02 \mathrm{c}$ \\
& & & \\
& 385.30 & 375.15 & 245.77 \\
$\mathrm{Na}$ & $\pm 7.11 \mathrm{a}$ & $\pm 12.03 \mathrm{~b}$ & $\pm 2.54 \mathrm{c}$ \\
\hline
\end{tabular}

Explanations as in Table 3.

determined using Student $t$ test at $p<0.05$. Statistical analyses of collected data were performed using the statistical package STATISTICA (data analysis software system).

\section{RESULTS AND DISCUSSION}

The physicochemical characteristics of the crude organic matter are presented in Table 3. Total solids (TS) content of the substrates studied varied within the range of $11.27-38.2 \%$. The lowest TS content was characteristic of carrot pomace $(11.27 \%)$ and the highest of maize silage (38.2\%). The kale by-products and the carrot pomace had dry TS contents higher than the values given in literature (Pitura et al., 2012; Tarko et al., 2012). Whereas, the parameters of the maize silage did not diverge from the literature data (Asam et al., 2011). The content of VS oscillated at a fairly constant level, from 91.27 to $95.6 \%$. The lowest content of VS was characteristic of kale by-products (91.27\% TS), and the highest - of maize silage (95.6\% TS). Carbon content of the substrates under study fell within the range of $36.3-55.7 \% \mathrm{TS}$, and organic nitrogen content $1.45-1.87 \%$ TS. For an anaerobic reactor to function properly, the dry matter content of the feedstock should be within the range from 5 to $15 \mathrm{~g} \mathrm{TS} 1^{-1}$ (Henze et al., 1997). In the course of the study the average concentration of the bioreactor feedstock was $6 \% \mathrm{TS}$. The $\mathrm{C} / \mathrm{N}$ ratio of organic waste was from 25.03 to $29.7 \%$, which is in agreement with literature data (Puyuelo et al., 2011). The elemental composition analysis of organic waste revealed significant differences in the content of potassium, phosphorus and sodium, probably caused by fertilization applied in the cultivation (Table 4). The elemental composition can be used as one of the indicators determining the usefulness of plant material for methane fermentation. In addition, determination of elemental composition has an extra meaning for the evaluation of potential usefulness of post-ferment sediments as fertilizer (Oleszek et al., 2014).

One of the fundamental parameters analyzed in the course of the process of anaerobic digestion was the amount of produced biogas and methane. On the basis of laboratory studies on the anaerobic digestion of biomass from the agriculture and food industry, the biogas and methane yields were calculated with relation to $1 \mathrm{~kg}$ of: fresh matter (fm), TS, and VS (Table 6). The good physicochemical properties of the experimental material resulted in high yields of biogas and methane. The highest productivity of 
T a b l e 5. Physicochemical properties of the methane fermentation process

\begin{tabular}{|c|c|c|c|c|c|}
\hline \multirow[t]{2}{*}{ Parameter } & \multicolumn{5}{|c|}{ Feedstock No. (Mean \pm S.D.) } \\
\hline & 1 & 2 & 3 & 4 & 5 \\
\hline Initial load of bio-reactor (TS\%) & $6.05 \pm 0.02$ & $6.12 \pm 0.01$ & $6.04 \pm 0.02$ & $6.08 \pm 0.03$ & $6.01 \pm 0.01$ \\
\hline $\begin{array}{l}\text { TS after fermentation } \\
\text { (wet weight } \% \text { ) }\end{array}$ & $4.95 \pm 0.9$ & $4.94 \pm 0.7$ & $4.48 \pm 0.65$ & $4.40 \pm 1.12$ & $3.98 \pm 0.82$ \\
\hline VS after fermentation (TS\%) & $64.36 \pm 1.1$ & $64.12 \pm 0.5$ & $63.98 \pm 0.45$ & $59.36 \pm 0.9$ & $55.67 \pm 0.5$ \\
\hline $\mathrm{N}_{\mathrm{am}}\left(\mathrm{g} \mathrm{NH}_{3}-\mathrm{N} 1 \mathrm{dm}^{-3}\right)$ & $1.34 \pm 0.45$ & $1.23 \pm 0.65$ & $1.25 \pm 0.50$ & $1.30 \pm 0.65$ & $1.24 \pm 0.37$ \\
\hline Total Nitrogen (TS\%) & $4.9 \pm 0.23$ & $5.1 \pm 0.12$ & $4.64 \pm 0.06$ & $5.3 \pm 0.1$ & $4.69 \pm 0.09$ \\
\hline $\mathrm{pH}$ & $7.1 \pm 0.03$ & $6.75 \pm 0.45$ & $6.9 \pm 0.32$ & $6.7 \pm 0.06$ & $7.0 \pm 0.58$ \\
\hline Total time of fermentation (day) & 30 & 30 & 30 & 30 & 30 \\
\hline
\end{tabular}

Explanations as in Table 3.

T a b l e 6. Biogas and methane yield in anaerobic digestion process from the feedstock substrates

\begin{tabular}{|c|c|c|c|c|c|c|}
\hline \multirow{2}{*}{ Feedstock No. } & \multicolumn{3}{|c|}{ Biogas yield (Mean \pm S.D.) } & \multicolumn{3}{|c|}{ Methane yield (Mean \pm S.D.) } \\
\hline & $\mathrm{N} \mathrm{dm}{ }^{3} \mathrm{~kg}^{-1} \mathrm{fm}^{-1}$ & $\mathrm{~N} \mathrm{dm}{ }^{3} \mathrm{~kg}^{-1} \mathrm{TS}^{-1}$ & $\mathrm{~N} \mathrm{dm}{ }^{3} \mathrm{~kg}^{-1} \mathrm{VS}^{-1}$ & $\mathrm{~N} \mathrm{dm}{ }^{3} \mathrm{~kg}^{-1}$ & $\mathrm{~N} \mathrm{dm}{ }^{3} \mathrm{~kg}^{-1} \mathrm{TS}^{-1}$ & $\mathrm{~N} \mathrm{dm}{ }^{3} \mathrm{~kg}^{-1} \mathrm{VS}^{-1}$ \\
\hline 1 & $14( \pm 3)$ & $125( \pm 12)$ & $135( \pm 13)$ & $7.95( \pm 1.5)$ & $71( \pm 4)$ & $76( \pm 5)$ \\
\hline 2 & $71( \pm 10)$ & $319( \pm 14)$ & $354( \pm 15)$ & $33( \pm 5)$ & $146( \pm 9)$ & $160( \pm 10)$ \\
\hline 3 & $85( \pm 7)$ & $226( \pm 9)$ & $270( \pm 10)$ & $36( \pm 3.5)$ & $96( \pm 5.5)$ & $114( \pm 6)$ \\
\hline 4 & $73( \pm 3)$ & $512( \pm 11)$ & $558( \pm 12)$ & $39( \pm 1.5)$ & $274( \pm 4.5)$ & $299( \pm 5)$ \\
\hline 5 & $192( \pm 4)$ & $503( \pm 7)$ & $526( \pm 8)$ & $107( \pm 2)$ & $279( \pm 4)$ & $292( \pm 6)$ \\
\hline
\end{tabular}

Explanations as in Table 1.

biogas was obtained in the case of the maize silage: $192 \mathrm{~N}$ $\mathrm{dm}^{3} \mathrm{~kg}^{-1} \mathrm{fm}^{-1}$, and the lowest from the carrot pomace: $14 \mathrm{~N}$ $\mathrm{dm}^{3} \mathrm{~kg}^{-1} \mathrm{fm}^{-1}$. The highest yield of biogas was obtained in the case of a mixture composed of carrot pomace and kale by-products: $512 \mathrm{~N} \mathrm{dm}^{3} \mathrm{~kg}^{-1} \mathrm{TS}^{-1}$, while carrot pomace alone was characterized by the lowest biogas yield: $125 \mathrm{~N}$ $\mathrm{dm}^{3} \mathrm{~kg}^{-1} \mathrm{TS}^{-1}$. Methane yields of the substrates studied were in the range of 71-279 $\mathrm{N} \mathrm{dm}^{3} \mathrm{CH}_{4} \mathrm{~kg}^{-1} \mathrm{TS}^{-1}$.

Zhang et al. (2007) and Narayani, Priya (2012) conducted methane fermentation of by-products from the food industry and noted lower results $\left(177 \mathrm{~N} \mathrm{dm}^{3} \mathrm{~kg}^{-1} \mathrm{TS}^{-1} ; 348\right.$ $435 \mathrm{ml} \mathrm{g}^{-1} \mathrm{TS}^{-1}$ ) than those presented in this work. Whereas, Kacprzak et al. (2010) obtained higher results comparing to this research, in the case of kale fermentation $(440-560 \mathrm{~N}$ $\mathrm{dm}^{3} \mathrm{~kg}^{-1} \mathrm{TS}^{-1}$ ) conducted at temperature of $35^{\circ} \mathrm{C}$, at $5 \%$ initial dry matter content.

The data for the anaerobic digestion may be also compared with earlier works. Cho and Park (1995) conducted mesophilic fermentation $\left(37^{\circ} \mathrm{C}, 28\right.$ days $)$ of food wastes and obtained the following amounts of methane -482 , 294, 277 and $472 \mathrm{ml} \mathrm{g}^{-1} \mathrm{TS}^{-1}$, respectively, for roast meat, cooked rice, cabbage, and a mix of food wastes. Whereas,
Hoe et al. (2004) achieved $489 \mathrm{ml} \mathrm{g}^{-1} \mathrm{TS}^{-1}$ of methane during co-digestion of food wastes. The mix was prepared at the following proportions: $10-15 \%$ of cooked rice, $65-70 \%$ vegetables, $15-20 \%$ meat and hen eggs. The fermentation was conducted for 40 days.

The highest methane content was characteristic of the biogas produced from maize silage (75\%) and from the mix of carrot pomace and kale by-products $(71.5 \%)$ (Fig. 1) on the 11th day of the process. The lowest concentration of methane was noted in the biogas produced from kale byproducts $(43 \%)$ and from carrot pomace $(45 \%)$. The time of fermentation was 30 days. Similar results were obtained by Zhang et al. (2007).

The analysis performed revealed that among the substrates proposed the highest economic productivity was obtained for the mix composed of carrot pomace and kale, formed as a by-product in processing plants $\left(558 \mathrm{~N} \mathrm{dm}^{3}\right.$ $\left.\mathrm{kg}^{-1} \mathrm{VS}^{-1}\right)$. Although the maize silage produced a fairly similar technological yield $\left(526 \mathrm{~N} \mathrm{dm}^{3} \mathrm{~kg}^{-1} \mathrm{VS}^{-1}\right)$, the economic effect was notably less favourable due to the cost of purchasing the silage, while the pomace, being a waste byproduct, was burdened only with the cost of transportation. 


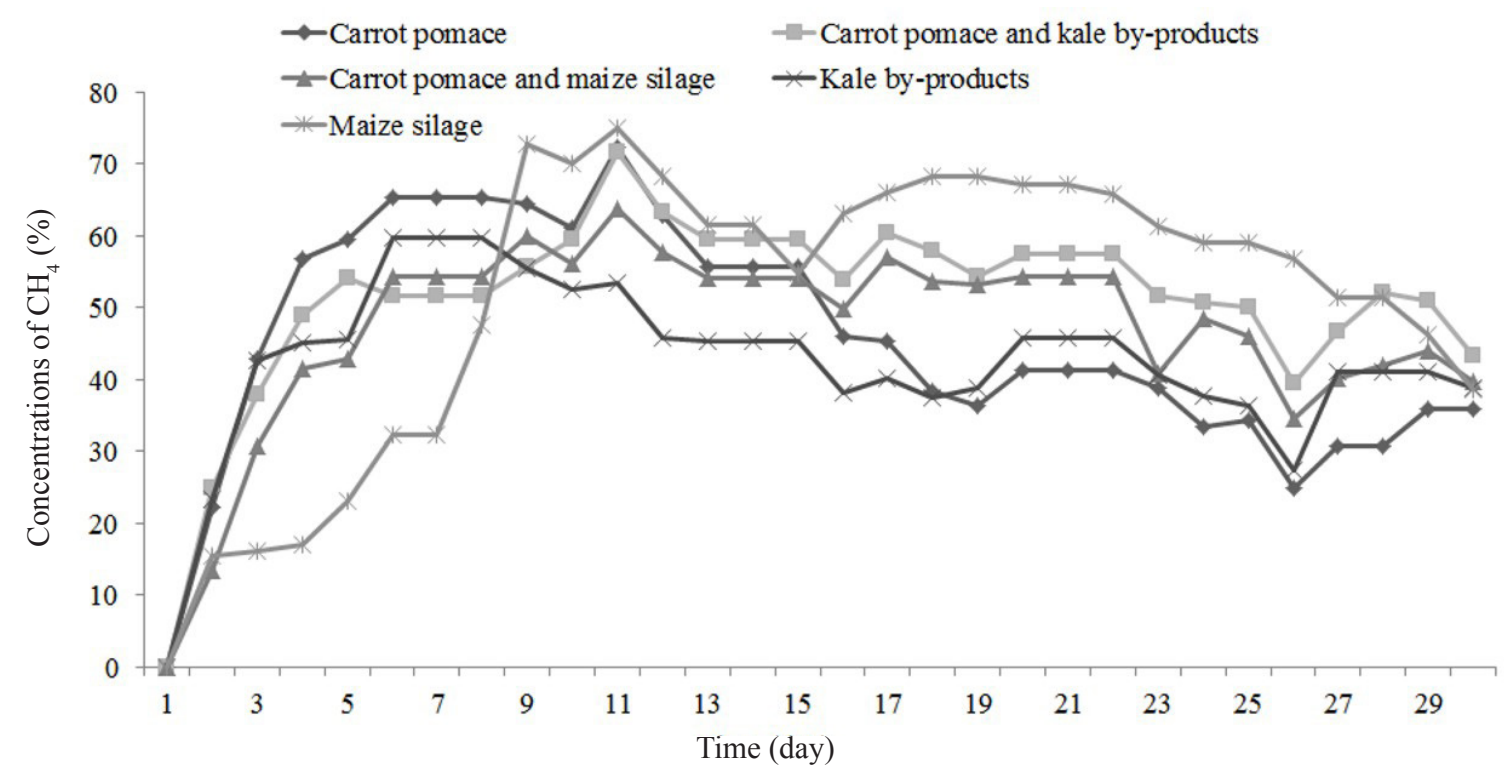

Fig. 1. Concentrations of $\mathrm{CH}_{4}$ for the particular feedstock substrates (\%).

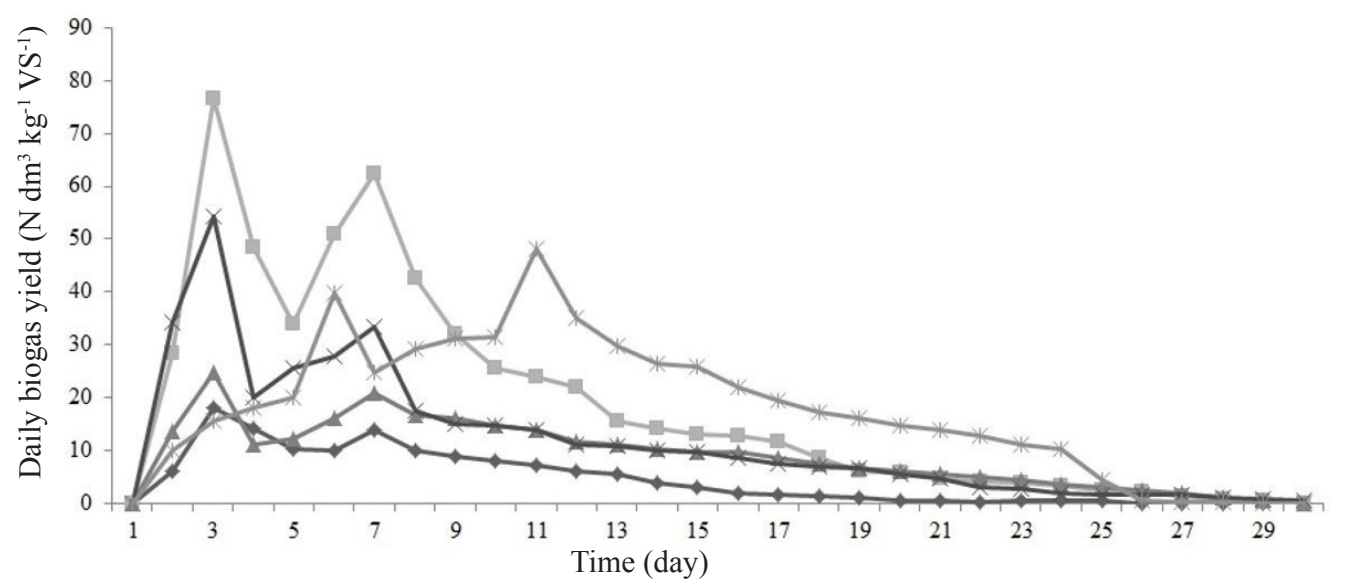

Fig. 2. Daily biogas yield for the particular feedstock substrates $\left(\mathrm{N} \mathrm{dm}^{3} \mathrm{~kg}^{-1} \mathrm{VS}^{-1}\right)$. Explanations as in Fig. 1.

Numerous studies indicate (Alvarez et al., 2008; Bouallagui et al., 2009; Fountoulakis et al., 2008) that anaerobic digestion with the use of waste materials from the food industry has a beneficial effect on biogas and methane yields. As reported by Dohanoyos et al. (2004) and by Jędrczak (2007), an addition of kitchen biowaste has a favourable effect on the effectiveness of biochemical transformations, mainly through raising the $\mathrm{C}: \mathrm{N}$ ratio of the mix being fermented.

The maximum efficiency of biogas production was observed between the 3rd and the 8th days of the methane fermentation process from the food industry wastes. Whereas, in the case of the maize silage, between days 6 and 12 (Fig. 2). The difference in the time of achie- ving the maximum efficiency of biogas production may be caused by considerably faster degradation of carbohydrates (main component of fruit and vegetable wastes) to simpler compounds available to methane bacteria, compared to the proteins and lipids contained in maize silage. Similar results were obtained by Sridevi and Ramanujam (2012) (Chen et al., 2008) who conducted methane fermentation of vegetable waste.

In the course of the process two distinct maxima of fermentation were observed. The notable decrease in biogas production between the highest values of the process may be the result of accumulation of propionic acid which is an inhibitor of the process of anaerobic fermentation (Shiguan et al., 2012). The flattened beginning of the graph of the 


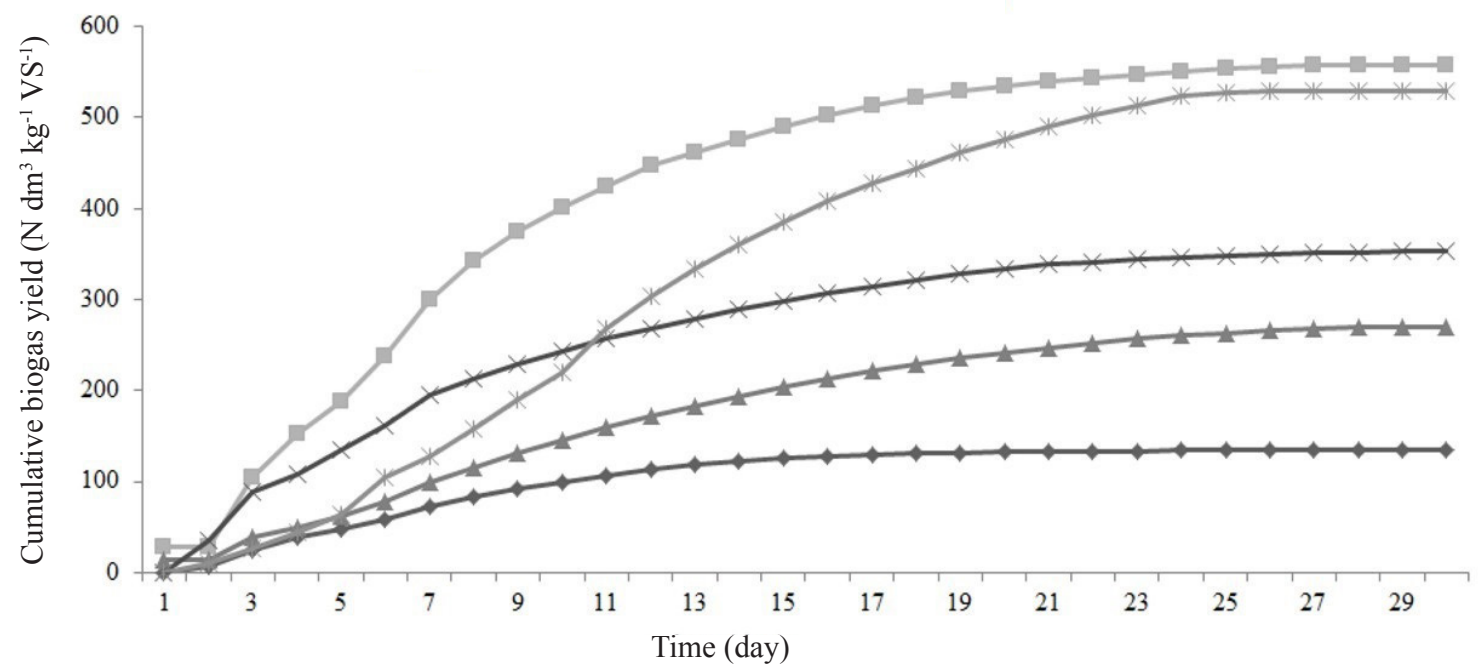

Fig. 3. Cumulative biogas yield for the particular feedstock substrates $\left(\mathrm{N} \mathrm{dm}^{3} \mathrm{~kg}^{-1} \mathrm{VS}^{-1}\right)$. Explanations as in Fig. 1 .

cumulative biogas yield indicated significant inhibition and delay of the hydrolysis process ( DIN 38414-8, 1985) and, consequently, the whole process of methane fermentation. Monlau et al. (2012) and Zhong et al. (2011) proved that this inhibition may have been caused by a high content of lignin. After reaching the maximum ie after days 8 and 12 of the process, the rate of biogas production began to decrease systematically and slowly faded to a stop.

The graph of cumulative biogas yield (Fig. 3) present the kinetics of the process of methane fermentation. The curve of biogas yield is adequate to the curve of bacterial culture growth. The exact shape of the growth curve depends on many factors, such as ambient conditions, kind and concentration of substrate (Monod, 1949).

Initially a slow increase was observed in the amounts of biogas per time unit (1-2 days of the process), which corresponds to the phase of adaptation, known as the lag phase. The duration of the lag phase largely depends on the period of acclimatization of the microorganisms to a specific substrate, moisture content, nutrients available in the substrate, $\mathrm{pH}$, and external factors such as temperature (Kacprzak et al., 2010; Mulka et al., 2011). After that stage, the amounts of biogas produced in a unit of time increased constantly. That was related with rapid growth of bacterial population. That phase is referred to as the phase of logarithmic growth. The duration of that phase is correlated with the rate of accumulation of toxic products of metabolism and with the availability of the substrate (Mulka et al., 2011). After reaching the point of deflection, a slight retardation of the rate of production was noted, followed by a state of equilibrium lasting until the end of the process, which is closely related with reduced efficiency of biogas production (Narayani et al., 2012).
Further part of the study comprised analyses of the physicochemical properties of the post-fermentate that, at the same time, provided information on the correct run of the process of methane fermentation (Table 5). The reaction, $\mathrm{pH}$, is an important parameter affecting the stability of the process of methanogenesis. The optimum range of $\mathrm{pH}$ is 6.8-7.4 (Miksch and Sikora, 2010). Too high a value of reaction, $\mathrm{pH}>7.5$, is dangerous as there is then an increase in the amounts of ammonia which is an inhibitor of the process. The value of $\mathrm{pH}$ of the feedstocks studied increased with extended time of hydraulic retention and oscillated within the range from 6.7 to 7.1 . That indicated correct run of the process of fermentation.

The fact of the composition of the mixtures being favourable for the process of methane fermentation was also supported by the determinations of ammonium nitrogen. The content of ammonium nitrogen $\left(\mathrm{NH}_{3}-\mathrm{N}\right)$ was in the range from 1.23 to $1.34 \mathrm{~g} \mathrm{dm}^{-3}$, ie according to Chen et al. (2007), below the concentration range from 1.7 to $14 \mathrm{~g}$ $\mathrm{NH}_{3}-\mathrm{N}$ in $1 \mathrm{dm}^{3}$ that causes inhibition of the process of fermentation.

\section{CONCLUSIONS}

1. The study demonstrated an improvement of the fermentation capacity of feedstocks in mix-fermentations. The mixing of fractions caused an increase in the intensity of biogas production during fermentation.

2 . The research permits the conclusion that the application of a substrate mix composed of carrot pomace and kale by-products will permit the achievement of biogas production with methane concentration above $50 \%$.

3 . While it is possible to conduct maize silage fermentation in the form of a single-component substrate, the study indicates that higher efficiency is achieved when the 
silage is fermented as a co-substrate in combination with the organic fraction of wastes from the food industry. That causes a more stable run of the process, and also co-fermentation permits the appearance of joint effects that may enhance the efficiency of organic matter degradation relative to methane yield.

\section{REFERENCES}

Alvarez R. and Liden G., 2008. Semi-continuous codigestion of solid slaughterhouse waste, manure and fruit and vegetable waste. Renewable Energy, 33, 726-734.

Asam Z-u-Z., Poulsen T.G., Nizami A-S., Rafique R., Kiely G., and Murphy J.D., 2011. How can we improve biomethane production per unit of feedstock in biogas plants? Appl. Energy, 88(6), 2013-2018.

Barton J.R., Issaias I., and Stentiford E.I., 2008. Carbonmaking the right choice for waste management in developing countries. Waste Manage, 28, 69-76.

Bekkering J., Broekhuis A.A., and van Gemert W.J.T., 2010. Optimisation of a green supply chain-a review. Bioresour. Technol., 101, 450-456.

Bouallagui H., Lahdheb H., Romdan E.B., Rachdi B., and Hamdi M., 2009. Improvement of fruit and vegetable waste anaerobic digestion performance and stability with co-substrates addition. J. Environ. Manag., 90, 1844-1849.

Börjesson P. and Berglund M., 2006. Environmental systems analysis of biogas systems-Part I: Fuel-cycle emissions. Biomass Bioenergy, 30(5), 469-485.

Chen Y., Cheng J.J., and Creamer K.S., 2008. Inhibition of anaerobic digestion: A review. Bioresour. Technol., 99(10), 4044-4064

Chi-Yang Y., Bo-Hong J., and Kow-Jen D., 2013. Production of bioethanol from carrot pomace using the thermotolerant yeast kluyveromyces marxianus. Energies, 6, 1794-1801

Cho J.K. and Park S.C., 1995. Biochemical methane potential and solid state anaerobic digestion of Korean food wastes. Bioresour. Technol., 52(3), 245-253.

Cuetos M.J., Go'mez X., Otero M., and Mora'n A., 2010. Anaerobic digestion and co-digestion of slaughterhouse waste (SHW): influence of heat and pressure pre-treatment in biogas yield. Waste Manage, 30, 1780-1789.

Cybulska J., Zdunek A., Sitkiewicz I., Galus S., Janiszewska E., Laba S., and Nowacka M., 2013. Opportunities of use the pomace and other waste products from fruit and vegetable industry (in Polish). Fermentation, Fruits Vegetable Industry, 9, 22-24.

DIN 38414-8, 1985. German standard methods for the examination of water, wastewater and sludge. Sludge and sediments (group S); determination of amenability to anaerobic digestion (S4) (in German). Beuth Verlag, Berlin. Germany.

Dohanyos M., Zábranská J., Kutil J., and Jenícek P., 2004. Improvement of anaerobic digestion of sewage. Water Sci. Technol., 49(10), 89-96.

Esposito G., Frunzo L., Giordano A., Liotta F., Panico A., and Pirozzi F., 2012. Anaerobic co-digestion of organic wastes. Rev. Environ. Sci. Biotechnol., 11(4), 325-341.

Fountoulakis M.S., Drakopoulou S., Terzakis S., Georgaki E., and Manios T., 2008. Potential for methane production from typical Mediterranean agro-industrial by-products. Biomass Bioenergy, 32, 155-161.
Frąc M. and Ziemiński K., 2012. Methane fermentation process for utilisation of organic waste. Int. Agrophys., 26, 317-330.

Henze M., Harremoes P., Jansen J., and Arvin E., 1997. Wastewater Treatment, Springer, Berlin, Germany.

Heo N.H., Par S.C., and Kang H., 2004. Effects of mixture ratio and hydraulic retention time on single-stage anaerobic co-digestion of food waste and waste activated sludge. J. Environ. Sci. Health, A39(7), 1739-1756.

Jędrczak A., 2007. Biological processing of wastes (in Polish). PWN Publishing, Warsaw, Poland.

Kacprzak A., Krzystek L., and Ledakowicz S., 2010. Studies of biochemical methane potential of selected energy crops (in Polish). Chemical Eng. Equipment, 49(4), 32-33.

Kotner M., 2011. Biogas in agriculture and industry, potential present use and perspectives. Renewable Energy World, 44, 133-143.

Lettinga G., 2001. Digestion and degradation, air for life. Water Sci. Technol., 44, 157-176.

Miksch K. and Sikora J., 2010. Biotechnology of Wastewater (in Polish). PWN Press, Warsaw, Poland.

Momoh O.L.Y. and Nwaogazie L.I., 2011. The effect of waste paper on the kinetics of biogas yield from the co-digestion of cow dung and water hyacinth. Biomass Bioenergy, 35(3), 1345-1351

Monlau F., Barakat A., Steyer J.P., and Carrere H., 2012. Comparison of seven types of thermo-chemical pretreatments on the structural features and anaerobic digestion of sunflower stalks. Bioresour. Technol., 120, 241-247.

Monod J., 1949. The growth of bacterial cultures. Annual Reviews Microbiol., 3, 371-394.

Mulka R., Szlachta J., and Szulczewski W., 2011. Modeling of the course of anaerobic digestion process, based on fundamental process control factors (in Polish). Agric. Eng., 9(134), 145-151.

Narayani T.G. and Priya T.G., 2012. Biogas production through fruit wastes biodegradation. J. Sci. Industrial Res., 71, 217-220.

Neves L., Oliveira R., and Alves M.M., 2009. Co-digestion of cow manure, food waste and intermittent input of fat. Bioresour Technol., 100, 1957-1962.

Nielsen H.B. and Angelidaki I., 2008. Strategies for optimizing recovery of the biogas process following ammonia inhibition. Bioresour Technol., 99, 7995-8001.

Oleszek M., Król A., Tys J., Matyka M., and Kulik M., 2014. Comparison of biogas production from wild and cultivated varieties of reed canary grass. Bioresource Technol., 156, 303-306

Oleszek M., Matyka M., Lalak J., Tys J., and Paprota E., 2013. Characterization of Sida hermaphrodita as a feedstock for anaerobic digestion process. J. Food Agric. Environ., 11(3,4), 1839-1841.

Oleszek M. and Tys J., 2013. Lab scale measurement of biogas yield. Przemysł Chemiczny, 1(92), 126-130.

Oslaj M., Mursec B., and Vindis P., 2010. Biogas production from maize hybrids. Biomass Bioenergy, 34, 1538-1545.

Pitura K., Michałojć Z., and Nowak L., 2012. The effect of potassium fertilizer kind and calcium on salinity, yielding and biological value selected vegetable species (in Polish). Annales UMCS, EEE, 22(3), 13-20. 
PN-EN 12879, 2004. Characterization of sludges. Determination of the loss of ignition of dry mass (in Polish).

PN-EN 12880, 2004. Characterization of sludge. Determination of dry residue and water content (in Polish).

Puyuelo B., Ponsá S., Gea T., and SánchezA., 2011. Determining $\mathrm{C} / \mathrm{N}$ ratios for typical organic wastes using biodegradable fractions. Chemosphere, 4 (85), 653-659.

Rehl T. and Müller J., 2011. Life cycle assessment of biogas digestate processing technologies. Resour. Conserv. Recycl., 56, 92-104.

Shiguan Y., Li J., Zheng Z., and Meng Z., 2009. Characterization of Spartina alterniflora as feedstock for anaerobic digestion. Biomass Bioenergy, 33, 597-602.

Siegert I. and Banks C., 2005. The effect of volatile fatty acid additions on the anaerobic digestion of cellulose and glucose in batch reactors. Process Biochem., 40, 3412-3418.

Sridevi D. and Ramanujam R.A., 2012. Biogas generation in a vegetable waste anaerobic digester: An analytical approach. Res. J. Recent Sci., 1(3), 41-47.

Tambone F., Genevini P., D'Imporzano G., and Adani F., 2009. Assessing amendment properties of digestate by studying the organic matter composition and the degree of biological stability during the anaerobic digestion of the organic fraction of MSW. Bioresour. Technol., 100, 3140-3142.
Tarko T., Duda-Chodak A., and Bebak A., 2012. Biological activity of selected fruit and vegetable pomaces (in Polish). Food Sci. Techno. Quality, 4(83), 55-65.

VDI 4630, 2006. Fermentation of organic materials. Characterisation of substrate, sampling, collection of material data, fermentation tests (in German). Beuth Verlag, Berlin, Germany.

Yoon K.Y., Cha M., Shin S.R., and Kim K.S., 2005. Enzymatic production of a soluble-fibre hydrolyzate from carrot pomace and its sugar composition. Food Chem., 92, 151-157.

Yuan X., Wen B., Ma X., Zhu W., Wang X., Chen S., and Cui Z., 2014. Enhancing the anaerobic digestion of lignocellulose of municipal solid waste using a microbial pretreatment method. Bioresour. Technol., 154, 1-9.

Zhang R., El-Mashad H.M., Hartman K., Wang F., Liu G., Choate C., and Gamble P., 2007. Characterization of food waste as feedstock for anaerobic digestion. Bioresource Technol., 98, 929-935.

Zhong W., Zhang Z., Luo Y., Sun S., Qiao W., and Xiao M., 2011. Effect of biological pretreatments in enhancing corn straw biogas production. Bioresour. Technol., 102, 11177-11182.

Ziemiński K. and Frąc M., 2012. Methane fermentation process as anaerobic digestion of biomass: Transformations, stages and microorganisms. Afric. J. Biotechnol., 11, 18, 4127-4139. 